Information Management and Business Review

Vol. 2, No. 3, pp. 112-117, Mar 2011

\title{
In-Store Promotions and Its Effect on Apparel Purchase
}

\author{
Satya S \\ Acharya Institute of Technology, Bangalore \\ ss.manuscript@gmail.com
}

\begin{abstract}
Indian retail sector is poised for growth and in-store is going to be the place where customers will take decision to spend or not to spend their money. As for apparel purchase, multiple factors influence the final decision on buying. Through this study, an attempt is made to find out the effect of in-store promotions and its influence on purchase of apparel by customers. Hence, the objectives of the study are set: to find out the customer's purchase intentions and actual purchase in the context of apparel buying; to find out the most effective in-store promotions that induces purchase of apparel. The study was conducted in two Reliance Trend outlets in Bangalore City, India. 750 customers were intercepted after their shopping with questionnaires. Analyses of data reveal that in-store promotions results in 87 percent of unplanned purchase in apparel buying. 80 per cent of the customers seek to visit the "Best buy" section within the store and instore display of large photographs induce trials of the same design to the tune of 72 per cent. When translated to money terms a customer spends Rs 400 to Rs 1200 on apparel, which was not in the planned list prepared before visiting the store. Hence, in-store promotions are effective means to induce on the spot buying decisions amongst customers especially in apparel purchase.
\end{abstract}

Key Words: In-store promotion, apparel purchase, unplanned purchase.

\section{Review on In-Store Promotions by Customers}

\section{Retail Sector in India}

Indian retail industry is the fifth largest in the world. It is one of the fastest growing industries in India. In the past, retail industry in India was mostly unorganized, with the change of tastes and preferences in the consumers; the retail sector is getting more organized. With growing market demand, retail industry is expected to increase at a pace of $25-30 \%$ annually. The India retail industry, which was $\$ 7.7$ billion (US) in 2004-05, is expected to grow to $\$ 24$ billion (US) by the year 2010 (Ganguly, 2010). It further adds that according to the 8th Annual Global Retail Development Index (GRDI) of AT Kearney's forecast, India retail industry is the most promising emerging market for investment. In 2007, the retail trade in India had a share of $8-10 \%$ in the GDP of the country. In 2009 , it rose to $12 \%$. It is expected to reach $22 \%$ growth in the near future. Studies on the Indian Retailing space by Kurt Salmon Associates reveal that "there are 5 million plus retail outlets in India. Of these 96 percent of the outlets are smaller than 500 square feet in area. This translates to the fact that Indian per capita retailing space is about 2 square feet compared to 16 square feet in the US, thus making the India's per capita retailing space the lowest in the world" (Ganguly, 2010)

\section{In-store Promotions in Retail Sector}

Dulsrud and Jacoben (2009) in their study highlighted that modern shopping space and super markets are the key arenas of sovereign and empowered consumers. The modern retail formats develop a new set of selling technique introduced to fill the void created by the absence of influential sales persons. They further mention that customers identify promotional activities with special areas within the stores. For example, "Four for the price of two" are located at end of aisle display or gondola ends. This activity is based on the assumption that shoppers naturally slow down to get around corners known as 'hotspots'. These also are the most profitable shelves in the stores.

According to Friedman (1980), modern supermarket is the ultimate arena of free choice. Considering the supermarket as a metaphor for political economy, the modern shoppers are described as sovereign, unmanageable, disloyal and exploring. Hayern and Brown (1990) examines that supermarket with multiple 
competitive brand stocked and displayed for sale in close proximity is a fierce battle field for various producers and brands. This study also concludes that brand loyalty remains strong even if competing brands are sold at a lower price and switching costs are low. Miller (1998) observes that in-store marketing program flourishes with words like 'free', 'economy', 'extra', 'more', 'value', 'saving', and 'bargain' thereby promoting ideas of value for money and reinforcing the shoppers' self conception as a 'rational consumer'. Abratt and Goodey (1990) examined unplanned buying in super markets. They point out that these unplanned buying in supermarkets is of interest to manufacturers as well as retailers. Manufacturers spend large sums of money each year advertising their brands to consumers, hoping to increase awareness, trail and ultimately the market share of products. Study aimed at measuring unplanned buying because of in-store stimuli in African super market and compared the results with US and Europe. The research covered 450 consumers in 15 major supermarkets in greater Johannesburg area covering North, South, East and Western suburban. 3 major super market chains were covered. Trained interviewers with a semi-structured questionnaire conducted face-to-face interviews in respondents' home language. Interviews were conducted pre and post shopping.

In-store stimuli are promotional technique employed to increase unplanned purchases of products. The techniques include in-store settings, on-shelf positions, price-off, sampling, point-of purchase displays, coupons, samples demonstrations to name a few. Abratt and Goodey (1990) found out that unplanned shopping was to the tune of 14 per cent in toilet soaps, 24 per cent in fizzy drinks and 9 per cent in toothpastes. The study concluded that stimulus responsible for unplanned purchase was as follows: Sign on shelf: $54 \%$, Price 14.5\%, Special display 8\%, Others 5\%, POP 4.5\%, Friend's suggestion 4\%, End of Aisle display 3.5\%, Ad recall 2\%, Family suggestion 2\%, Size/ package 1\%, Special Offer 1\% and In-store advertisement $0.5 \%$. Kessler (2004) points out that retailer worldwide are not only aware of their growing power, but flex their muscles and squeeze margins regularly. Brands respond to this in a variety of ways and one of them is in-store marketing and display. Research by point of purchase advertising institute (POPAI) has shown that $75 \%$ of purchase decisions are made in-store. Consumers have a profile of brands that they will consider purchasing and the choice of which one to buy is made at the moment a brand selection inside the store.

\section{Purchase of Apparel}

There are innumerable studies on fashion, purchase of fashion accessories, purchase of clothing in various contexts and backgrounds. The study by Karpova, Hodges and Tullar (2007) examines post socialist consumer experience in the context of clothing consumption practices when consumers shop, acquire and wear clothing and other fashion related products. Consumer behavior on post socialist period in Russia was understood through a primary data study. Interviews were conducted with 4 male and 13 female students. Consumer behaviors vary distinctly in the post socialist market where qualities, brand name, country of origin, retail channel are critical for buying decisions. Appearance and clothing play a special role in emerging Russia as they communicate new identities. Findings reveal that there is opportunity for domestic and foreign apparel businesses to cater to the middle class retail market. Customers perceive two ends one with very expensive, high quality, stylish apparel and on the other end the inexpensive low quality apparel. Currently most of the fashion apparel manufacturers and retailers target to younger consumers.

Park, Kim \& Forney (2006) explored casual relationship among fashion involvement, positive emotion, and hedonic consumption tendency in the context of fashion shopping. The study aimed at understanding fashionoriented impulse buying through a self-administered questionnaire. This study was conducted amongst 217 college students. Findings revealed that positive emotions had positive effects on consumer's fashion oriented impulse buying behavior with fashion involvement having the greatest effect. Hedonic consumption that is purchase for pleasure; determines fashion oriented impulse buying. The study revealed that store design, product display, package design focusing on entertainment, interest and excitement is as important as getting the right mix of merchandise and pricing.

Bellman, Inteich, and Clark (2009) studied fashion accessories and 'self-creation' by clients on young women born between 1982 -2001, who frequent mall of American shopping complex in Minneopolis. Customizing consumer products has existed for many decades. Motivation factors that affect consumer's attitude and 
intention to "self- create" "off the shelf" products are explored in this study. Through this research willingness to use fashion accessories as a means of self-expression was explored. A pilot study was conducted to find out the inclination to spend time in a store offering to create customers own handbags. Survey instrument was created using the traditional TRA model. International and behavioral theory components were measured using 6-point scale. It was observed that younger people seem to be more influenced by peer opinions and as a person ages and matures, she is capable of making more decisions that are independent. Findings reveal that significant opportunity is available for entrepreneurs to open 'create your own handbag' retail establishment that may attract pre-teens and young teens. It also suggests that shopping environment exhibited strong attitudes towards creating clothing accessories on their next mall visits. The same idea can be extended to other possible segment that is; young male to create their own computer games.

Exploring how apparel is purchased and who influences purchase decisions is of most importance to the fashion industry. Through a study, Seock and Bailey (2008) explore Hispanic consumer's use of personal and impersonal information sources and examine age and gender difference in the use of information for apparel shopping. This study was conducted through self-administered questionnaire. 400 sample based on convenience was selected from Hispanic consumers living in Southern State of USA. Of the 400 studied, 336 completed responses were used for analysis of data. Personal information sources that influenced purchase decisions were found to be 1.Father, 2.Mother, 3. Sister, 4. Other family members, 5 . Brothers or other male family member 6. Friends (girlfriend/boyfriend) and 7. Sales Person. Impersonal information that influenced purchase decisions includes 1. Fashion magazine, 2. Non-fashion magazine, 3.Catalogues 4. Internet 5.TV 6.Celebrities 7.0bserved Street wear and 8.Store Display. Results from the study reveal that among the personal influence sources used for seeking opinion in apparel purchase decision; boy friend/girlfriend received the highest mean source for respondents under 20 years, followed by friend, mother, sister and other family members. For age group of 30, friends followed by boy/girl friend were the most influential. Sales personnel's attitude and manner towards customers and their knowledge and expertise were identified as important in influencing older Hispanic customer's purchase decision at the stores. Among the eight impersonal information sources used for gathering ideas for purchasing apparel items, store display had the highest mean score for all respondents, regardless of age and gender difference, followed by observed street wear. It is clear that Hispanic consumer is most likely to gather information about clothing items from store display and observed street wear.

The literature reviewed in the earlier sections, clearly shows that retail sector is poised for growth in India and in-store is going to be the place where customers are going to take decision to spend or not to spend their money. For purchase of ready to wear apparel, it is evident that the buying decision is a complicated process. Multiple factors influence the final call on choice of purchase. Thus, the objective of this study is set as follows:

1. To find out the customer's purchase intentions and actual purchase in the context of apparel buying;

2. To find out the most effective in-store promotions that induces purchase of apparel.

\section{Reliance Trend the Apparel arm of Reliance Retail}

According to the company web site Reliance Trends, offers quality and fashionable clothing at low prices, is chalking out major expansion plans. The apparel arm of Reliance Retail is set to expand its current base of 16 stores across the country to 155 by 2012, spanning over 90 cities in India. According to senior company officials, with their incredible price offering, "Reliance Trends" is all set to revolutionize the apparel industry in India. Reliance Trends' mission is to offer the common man quality and fashionable clothing at remarkably low prices. After a relatively slow start, the company plans to move ahead aggressively. The focus of Reliance Trends is affordability. At every stage of making a garment, the company tries and save every rupee without compromising on the quality. Right from sourcing raw materials to choosing business partners and designing, pricing is kept in the forefront. The biggest business for Reliance Trends is from the private labels and nearly 60 per cent of the retail outlet's revenue comes from the private brands. Besides this Reliance Trends also stocks leading national and international brands. Among the many exciting offerings from Reliance Trends are First Class jeans at just Rs 199. An anti-wrinkle business suit prices at around Rs 4,500 on an average in other retail stores are priced at Rs 2,499 at Reliance Trends. Among others, Reliance Trends also has a collection of technology clothes. These are fragrant clothes for infant, stain-free trousers, shirts and trousers 
with in-built moisture management. Recently, Reliance Trends got an award in the Asia Retail Congress: "The Retail Marketing Campaign" of the year Award.

\section{Method of Study}

This study was conducted in two "reliance trend" showrooms situated in Bangalore, India. Structured questionnaire was prepared to find out the consumer's reactions on purchase intention, planned purchase, and unplanned purchase of apparel. The questionnaire also explored the most effective in-store promotions, which induces trial or purchase of apparels. 16 questions were set to five-point scale to elicit information on prior planning of purchase, actual purchase, unplanned purchase, what in-store promotions actually induced unplanned purchase. Five questions were set to elicit information on demographic details. While one "reliance trend" showroom is a standalone outlet, the second one is situated inside a mall with many other outlets displaying ready to wear attires. Two trained field staff placed outside the retail showrooms collected data from the shoppers. Convenient sampling was used and customers who were getting out of the retail store after the shopping were intercepted. After explaining the nature of the study and getting the consent, the field staff, through a face-to-face method administered the questionnaire to the customers. The field staff collected data from $1 \mathrm{pm}$ to $8 \mathrm{pm}$. It was observed that sales picked up after $5 \mathrm{pm}$ and peaked till $8 \mathrm{pm}$. It took 15 to 20 minutes to complete a questionnaire and in all 750 customers were contacted for the study. Data were compiled in excel sheets.

\section{Findings and Discussion}

The demographic profile reveals that 75 per cent of all respondents were females. 60 percent of these were in the age group of 35 to 45 . It was observed that 52 percent of the women were working, and the remaining were homemakers. The shoppers spent close to 45 minutes in the outlet and felt that the shopping ambience inside the outlet was pleasant. Afternoon was the time for the homemakers to shop; the working people visited the shop with family or friends in the evening. It is observed that a whooping majority of 87 per cent of the customers bought apparels that they had not planned to purchase before entering the stores. This indicates that customers make purchase decision after seeing the selection and range in the stores. The average amount that is spent on unplanned purchase ranges from Rs 400 to Rs 1200 during a visit. This clearly indicates that in-store is the most effective place where purchase decisions are made. Newspaper advertisement and word of mouth could bring people to the store, but completing a purchase process is crucial for sales and profits. This study clearly indicates that decision for purchase is taken inside the store after examining the range, style and display induced by in-store promotions.

In-store promotions are rated very important by 67 per cent of the customers in making their decisions to purchase and go for the final buy. Though signboards and good displays inside the store are important, price offers were the curial factor that wrapped purchase decisions. Amongst students, trendy design and price points are the two factors considered equally important to make decisions on purchase, While 80 per cent of the customers went looking for the "best buy" section within the store, the remaining 20 per cent came across the best buy section because of its prominent location and customers crowding the shelves. During the course of the data collection, the best buy section made jeans available for Rs 199 and it was greatly sought after by the customers. They felt that the offer was great and genuine. 82 percent of the customers found the private label section was the most attractive in the store. This section of the store is loaded with private brands of casual shirts, formal shirts, dresses, t-shits, track pants that is unique to "Reliance Trends". These apparels are not available in completive stores like Lifestyle and Shopper's Stop. The apparels available here also suits the Indian frames and body structure and 63 per cent of the women opined that they were able to find their right sizes and were wanting more varieties and fashions designed for Indian women. Women felt that casual shirts and formal shirts are often available for teen agers in international branded outlets like Benetton and Lee, but the middle age women are not too happy with the designs and fittings of the international brands. The international apparel brand's fittings, necklines, color range does not exactly cater to the Indian taste and body frame. Since reliance has its own sourcing and fashion designing units, it can address this gap and get apparels to cater to the middle-aged women, who are keen in wearing blouses, casual and formal shirts. This market is clearly left out by the international brand. Indian middle-aged women are shifting to wearing jeans and trousers as westernization is sweeping the whole world. 
End of aisle display and mannequins placed inside the stores also helped in inducing spot decisions to purchase to the extent of 35 per cent. Though the assistance from sales staff is rated very important by 82 per cent of the respondents, the availability of the right design and the right size were the factors that leads the final purchase decision. Large photographs of models decorating the walls with a particular attire made customers ask for the same design and color to the tune of 72 per cent. In-store managers need to note this factor as most of the store managers sell the spots to established international brand owners. Since 60 per cent of reliance trend products are private brands, it is advisable that these designs are displayed in the stores through eye-catching photographs and on wall displays, instead of selling the space to established brands. Though revenue is generated by letting out this space to established international brands, it would be a prudent decision to promote in-store brand and induce customers to buying it. It is also significant to mention that retailers get more margins by selling private labels than through sales of international brands, especially so in the apparel industry. Hence, in- store revenue can be planned considering the fact that movements of the private brands will offer more margins than letting the space for promotions to established brand like Tommy Hilfiger, Lee, and Wrangler. Shopping habits in India is very distinct as purchase decision of apparels especially the ones purchased for festivals and functions are family decisions than individualistic desire and taste. Buying formal dresses is not limited to the liking of an individual but the approval of parents also plays an important part. Based on occasion of the purchase, decision-making patterns vary. 74 per cent of school goers and pre degree students still shop with parents and their approvals were important in finalizing the purchase. This was not true with the young working professional as 92 per cent of them shop with friends and colleagues. While westernized styles were welcome by both the target groups, 93 percent dismissed a completely western design, as it was inappropriate and not "wearable" in India.

As far as opinions on the apparel range, 65 percent felt that the range was good. Customers suggest that variety can be increased in the infant section too. The stores have two separate sections for children and infant and the infants section has very limited styles. The women section displaying saris and salwar kameez suits (Indian dresses) were considered appreciable but not unique by 83 per cent of the customers. 90 per cent of the customers felt that scope to innovate in-store promotions were abundant considering the range of products available in Reliance trend. Some of the ideas that evolved during the study are enlisted below:

1. For purchase of casual shirts over and above Rs. 500 , a discount of Rs. 50 can be offered $(10 \%$ of the cost of the shirt) for purchase of earnings or chains, bracelets or finger rings. Accessories purchase can be bundled with apparel purchase and this will enable good flow of customer traffic in both the areas. The retail space is planned in such a way that the apparel and the accessories are in the same level. The accessory division located at the entrance currently can be shifted to the end enabling apparel shopping first. The floor plan can be planned in such a way that the customers are lead to the accessory division where they can coordinate their garments with accessories.

2. Similarly, purchase of formal wears can be bundled with price-off on color cosmetics like nail polish, lip shades and eye makeup.

3. Handbags or other accessories like hair bands, belts, purses, sling bags, wristbands, ear wear can sell in "combination offers" along with the apparel. A "combo offer" will add more items to the buying cart. Pricing should be designed in such a way that addition of more items in the "combination" would result in more percent of discount on each added product.

Implementing these suggestions will not only increase the overall billing, but will also encourage the customers to visit sections that they otherwise would not visit. Place is of premium in malls. The amount spent on air-conditioning, staff, display will be spent well if the customers are made to get around the showroom and take interest in viewing all the section. Finishing their targeted purchase in a particular area and exiting from the store may also lead to low loyalty levels. Through bundling offers, there is a stage set for the customer to visit more sections within the store and this paves ways to next purchase and an opportunity for the sales supervisors to demonstrate new products and give a good shopping experience inside the store. 85 per cent of the shoppers in "Reliance trend" were sure that they will visit the shop every month or every six weeks to check on the new arrivals and designs. Consumers appreciate the size of the store, the layout of the floor space and the ambiance and they describe the environment "conducive". However, more than 40 percent of the weekend shoppers felt that the services at the billing could be made efficient and fast. 


\section{Conclusion}

Reliance trend was perceived as value for money destination for casual wear. Customers differentiate it from Shoppers Stop, Lifestyle, Provogue, Benetton, Lee as Reliance stocks private labels. Having a fashion analyst to study trends to suit Indian fittings and sourcing the right materials from vendor will not only develop the vendor base but will add importance and increase the value chain of the supply. Exploring new sizes and design to suit the Indian middle age segment with private brands will open doors to new markets, which is still not addressed by international brands. Wall mounts with model's photographs exhibiting a particular design induces trail. Increasingly, in-store is the space where purchase decisions will be made as apparel buying is more of an instant decision than a planned one. Bundling of accessories with apparel purchase and adding more items into the cart with attractive discounts can promote customers to take interest into other sections, which they had not planned to visit. Since each retail outlet in its lay out and in-store, promotions the same study can be conducted amongst other retailers in the same category namely Shopper's Stop, and Lifestyle. One of the limitations of the study was to convince the shoppers for a face-to-face administration of the questionnaire. The shoppers had other agendas for the day and did not want to spend time for the research. The store can collect data during payment and the customers can be contacted later for an online study.

\section{Reference}

Abratt, R. \& Goodey, D. S. (1990). Unplanned Buying and in store Stimuli in Super Markets. Managerial and Decision Economics, 11(2): 112-121.

Bellman, M. L., Inteich, S. \& Clark, D. (2009). Fashion Accessory Buying Intentions Among female Millennial. Review of Business, 30(1): 46-58.

Dulsrud, A. \& Jacoben, E. (2009). In-store marketing as a Model of Discipline. Journal of Consumer Policy. 32: 203-218.

Friedman M, Friedman. (1980). Free to Choose: A Personal Statement. New York: Harcourt Brace Jovanovich.

Ganguly, S. (2010). Retailing Industry in India, Retrieved from http//www.indiaonestop.com/retailing.html.

Hayern, D. W., \& Brown, P. S. (1990). Effect of Brand Awareness on Choice for Repeat Purchase Products. Journal of Consumer research, 17: 141-148.

Kessler, C. (2004). Branding in-store Marketing in the 21 $1^{\text {st }}$ Century. Journal of Brand Management, 11(4): 261264.

Karpova, E., Hodges, N. N., and Tullar, W. (2007). Making Sense of the Market: An exploration of Apparel Consumption Practices of the Russian Consumer. Journal of Fashion Marketing and Management, 11(1): 106-121.

Miller, D. (1998). The Theory of Shopping. Itaca. Cornell University Press.

Park, J. E., Kim, Y. E., and Forney, C. J. (2006). A structural Model of Fashion Oriented Impulse Buying Behavior. Journal of Fashion Marketing and Management, 10(4): 433-446.

Seock, K. Y., \& Bailey, R. L. (2008). Fashion Promotion in the Hispanic Market. Hispanic Consumer's use of Information Sources in Apparel Shopping. International Journal of Retail and Distribution Management, 37(2): 161-181. 